\title{
Potential Use of Apple Polyphenol Oxidase for Bioremediation of Phenolic Contaminants
}

\author{
A. Šalić, ${ }^{a}$ I. Strelec, ${ }^{b}$ B. Zelić, a and M. Tišmab* \\ a University of Zagreb, Faculty of Chemical Engineering and Technology, \\ Marulićev trg 19, HR-10 000 Zagreb, Croatia \\ b Josip Juraj Strossmayer University of Osijek, Faculty of Food Technology Osijek, \\ Franje Kuhača 20, HR-31 000 Osijek, Croatia
}

\begin{abstract}
Phenolic compounds, such as catechol, are released into the environment from a variety of industrial sources and they present a serious ecosystem burden. This work examined the possibility of using partially purified apple polyphenol oxidase (PPO) for bioremediation of phenolic contaminants. In order to optimize process conditions, the optimal $\mathrm{pH}$ and temperature for PPO activity were determined, while PPO affinity toward various phenols, as well as the effect of some salts and organic solvents which can be found in wastewaters, was used to confirm applicability of PPO in wastewater treatment. It was found that partially purified apple PPO shows maximal activity at $\mathrm{pH} 6.8$ and $25^{\circ} \mathrm{C}$, but exhibits more than $85 \%$ of its maximal activity in pH range from 5 to 8 , and more than $90 \%$ of activity in temperature range from 10 to $50{ }^{\circ} \mathrm{C}$. PPO showed high affinity for various diphenols, but lack of affinity toward monophenols. Sodium tetraborate decahydrate moderately inhibited PPO activity, while exposure of PPO to the presence of organic solvents $(\varphi=5 \%$ ) caused $40 \%$ loss in its activity. Catechol oxidation by PPO performed for just 5 min in a batch reactor at optimal process conditions resulted in $25 \%$ conversion. Based on obtained data, it seems that partially purified apple PPO has reasonable potential in wastewater treatment.
\end{abstract}

Keywords

Catechol oxidation, enzymatic wastewater treatment, phenolic contaminants, polyphenol oxidase (PPO)

\section{Introduction}

Wastewater discharged from a number of processing industries, such as production of rubber, dyes, pesticides, colours, plastics, pharmaceuticals, and cosmetics, contains dissolved organic pollutants such as phenol and substituted phenolic compounds. ${ }^{1}$ The United States Environmental Protection Agency (EPA) has ranked phenols the $11^{\text {th }}$ on a list of 126 toxic chemicals that have been designated as priority pollutants. ${ }^{2}$ Their concentration usually ranges from 100 to $1000 \mathrm{mg} \mathrm{I}^{-1}$ and they present a serious toxic and hazard threat to the environment. ${ }^{3}$ According to some regulations, the concentration of phenols in the industrial effluents should not exceed 0.05 to $1 \mathrm{mg} \mathrm{l}^{-1}$ for safe discharge in sewage and in marine environment. ${ }^{4}$ Many different methods, physical and chemical (destructive oxidation, adsorptive micellar flocculation, ultrafiltration and adsorption on organic and inorganic compounds) and biological (phytoremediation and microbiological removal), have been applied for removal of those toxic compounds from wastewaters. ${ }^{4,5}$ Although chemical and physical methods have been investigated exhaustively, they have many drawbacks, such as high costs, incomplete removal, formation of hazardous by-products that are even more toxic than phenols, low efficiency, high energy requirements and/or applicability only in a low range of concentrations. ${ }^{6}$ On the other hand, there is a growing recognition that enzymes can be used in many remediation processes to target specific pollutants for treatment. ${ }^{7}$ Application to different substrates, operation at high and low contaminant

*Corresponding author: Assoc. Prof. Marina Tišma, PhD

e-mail: mtisma@ptfos.hr concentrations over a wide $\mathrm{pH}$, temperature and salinity range, and easy control are just some of the advantages of enzymatic processes. ${ }^{8}$ The idea of using oxidoreductive enzymes, like polyphenol oxidase (PPO) and peroxidase, for wastewater treatment was developed in the early 1980s. ${ }^{9}$ PPOs became interesting because they are widely distributed through different microorganisms, plants and animals, and specific to a wide range of phenolic substrates transforming them to less toxic and insoluble quinones ${ }^{5}$, making the separation much easier. They can be applied as free or immobilized enzymes, purified or crude extract. Among them, the least desirable is the use of purified free enzyme because they are non-reusable and highly sensitive towards denaturation agents. Therefore, immobilized enzyme, partially purified and even crude extract of PPO are more desirable forms. ${ }^{10,11}$ Researchers have found that the presence of different enzymes and isoenzymes along with other non-enzyme constituents in crude extract permits the extract to function under a wider range of conditions ( $\mathrm{pH}$, temperature, polyphenol concentration), and with more substrates than would be possible using single enzymes. ${ }^{12}$

This study reports the possibility of using partially purified PPO from apple variety Idared for catechol removal from aqueous media. Catechol was chosen since it provokes changes in the function of erythrocytes at doses as low as $50 \mu \mathrm{g} \mathrm{I} \mathrm{I}^{-1}$ i.e. that dose for phenol is $250 \mu \mathrm{g} \mathrm{I} \mathrm{I}^{-1}{ }^{13}$ Characterization of partially purified PPO from apple variety Idared was studied in terms of $\mathrm{pH}$, temperature, and storage stability. Besides catechol, several different phenolic compounds were studied as possible substrates for partially purified apple PPO. The focus was also on the degree of 
inhibition by different inhibitors, to help predict the behaviour of the apple enzyme in complex media, such as in wastewater loaded with different phenolic compounds.

\section{Experimental}

\subsection{Chemicals}

Ammonium sulphate, acetone, dimethyl sulfoxide (DMSO), ethanol, ethylenediaminetetraacetic acid disodium salt (EDTA-2Na), and sodium chloride were purchased from Kemika (Croatia). Bradford reagent was purchased from Bio-Rad (Germany). L-3,4-dihydroxyphenylalanine (L-DOPA), (+)-catechin, caffeic acid, chlorogenic acid, (-)-epicatechin, 4-methylcatechol, trans-ferullic acid, (-)-epigallocatechin-3-gallate, bovine serum albumin, sodium tetraborate decahydrate, and catechol were purchased from Sigma-Aldrich (USA). L-tyrosine, sodium phosphate monobasic monohydrate, and sodium phosphate dibasic dihydrate were purchased from Merck (Germany), while Triton X-100 was purchased from Fluka (Germany).

\subsection{Partial purification of apple polyphenol oxidase}

Apples (Malus domestica cv. Idared) of commercial maturity, marked as Croatian product, purchased at a local store (Konzum, Croatia) were used as starting material for isolation of PPO. Apples of the variety Idared were chosen since they are the most common cultivar in Croatia (60\% of total apple production) and $4^{\text {th }}$ in the European Union. ${ }^{14}$

Polyphenol oxidase from apples was partially purified by ammonium sulphate (30-80 \%), and subsequent ice-cold acetone $\left(-20{ }^{\circ} \mathrm{C}\right)$ precipitation according to Strelec et al. ${ }^{15}$ Brownish acetone precipitate collected by centrifugation (15.000 g, $20 \mathrm{~min}, 4^{\circ} \mathrm{C}$; Heraeus Multifuge 3L-R Centrifuge, Heraeus, Germany) containing PPO (5018 $\left.\pm 198 \mathrm{U} \mathrm{mg}^{-1}\right)$ was stored at $-20^{\circ} \mathrm{C}$ and used for all experiments.

\subsection{Determination of protein concentration}

Protein concentrations in extracts and PPO solutions were measured according to the method of Bradford ${ }^{16}$ using bovine serum albumin as the standard.

\subsection{PPO activity assay}

PPO activity was determined spectrophotometrically at $25{ }^{\circ} \mathrm{C}$ using a double-beam spectrophotometer Specord 200 (AnalytikJena, Germany), by measuring the absorbance at $475 \mathrm{~nm}$ or $420 \mathrm{~nm}$, depending on the substrate. Change in absorbance was recorded every $10 \mathrm{~s}$ during $100 \mathrm{~s}$ for all substrates, except L-tyrosine, where the change in absorbance was recorded every $30 \mathrm{~s}$ during $15 \mathrm{~min}$. One unit of PPO activity $(\mathrm{U})$ was defined as the change in absorbance of 0.001 per min and per $\mathrm{ml}$ of enzyme. All the measurements were performed in triplicate, and in the $95 \%$ confidence interval the results showed no significant difference.

\subsection{Determination of $\mathrm{pH}$ and temperature optimum}

The influence of $\mathrm{pH}$ on PPO activity was measured at $T=25{ }^{\circ} \mathrm{C}$ in the $\mathrm{pH}$ range from 5 to 9 using various buffers: a) $0.1 \mathrm{mmol} \mathrm{I}^{-1}$ sodium acetate buffer of $\mathrm{pH} 5$ and 6 ; b) $0.1 \mathrm{mmol} \mathrm{I}^{-1}$ sodium phosphate buffer $\mathrm{pH} 6,6.8,7$ and 8 , and c) $0.1 \mathrm{mmol} \mathrm{I}^{-1}$ Tris- $\mathrm{HCl}$ buffer of $\mathrm{pH} 8$ and 9 . L-DOPA $\left(10 \mathrm{mmol} \mathrm{I}^{-1}\right)$ was used as a model substrate.

The influence of temperature on PPO activity was measured in temperature range between 10 and $50{ }^{\circ} \mathrm{C}$, while thermal stability of the enzyme was determined by incubating the enzyme solution at temperature of $4{ }^{\circ} \mathrm{C}$ and $25^{\circ} \mathrm{C}$ up to $160 \mathrm{~h}$. In both cases, L-DOPA (10 mmol I-1 in $0.1 \mathrm{mmol} \mathrm{I}^{-1}$ phosphate buffer, $\mathrm{pH} 6.8$ ) was used as a substrate.

All the measurements were performed in triplicate, and in the $95 \%$ confidence interval the results showed no significant difference.

\subsection{Determination of enzyme stability}

The stability of PPO solution $\left(250 \mathrm{U} \mathrm{mg}^{-1}\right.$ of PPO suspended in $0.1 \mathrm{mmol} \mathrm{I}^{-1}$ phosphate buffer, $\mathrm{pH} 6.8$, containing Triton X-100 $(\varphi=0.1 \%))$ was monitored during seven days of storage at 4 and $25{ }^{\circ} \mathrm{C}$, while storage stability of partially purified PPO was monitored during 228 days of storage at $-20{ }^{\circ} \mathrm{C}$. All the measurements were performed in triplicate, and in the $95 \%$ confidence interval the results showed no significant difference.

\subsection{Substrate specificity of apple PPO}

Substrate specificity of PPO was determined using nine different substrates: L-3,4-dihydroxyphenylalanine (L-DOPA), (+)-catechin, caffeic acid, chlorogenic acid, (-)-epicatechin, (-)-epigallocatechin-3-gallate, 4-methylcatechol, trans-ferullic acid and L-tyrosine. Reaction mixture for PPO activity determination contained $1,2.5$, or $10 \mathrm{mmoll}^{-1}$ substrate solution in $0.1 \mathrm{mmolI}^{-1}$ phosphate buffer, $\mathrm{pH} 6.8$, and $250 \mathrm{U} \mathrm{mg}^{-1}$ of PPO suspended in $0.1 \mathrm{mmoll}^{-1}$ phosphate buffer, $\mathrm{pH} 6.8$ at $T=25^{\circ} \mathrm{C}$, containing Triton X-100 $(\varphi=0.1 \%)$. Increase in absorbance at $420 \mathrm{~nm}((+)$-catechin, caffeic acid, chlorogenic acid, (-)-epicatechin, (-)-epigallocatechin-3-gallate, 4-methylcatechol, trans-ferullic acid) or $475 \mathrm{~nm}$ (L-DOPA and L-tyrosine) was measured. All the measurements were performed in triplicate, and in the $95 \%$ confidence interval the results showed no significant difference.

\subsection{Effect of inhibitors and organic solvents on PPO activity}

PPO activity was measured in the presence of three different inhibitors (ethylenediaminetetraacetic acid disodium salt, sodium chloride, and sodium tetraborate decahydrate (borax)) at three different concentrations in the reaction mixture $\left(0.1,1\right.$ and $\left.10 \mathrm{mmol} \mathrm{I}^{-1}\right)$ containing $10 \mathrm{mmol} \mathrm{I}^{-1}$ L-DOPA as a substrate $\left(T=25^{\circ} \mathrm{C}\right)$. 
The effect of two organic solvents, dimethyl sulfoxide and ethanol, on PPO activity was measured at three different solvent volume percentages $(1,2$ and $5 \%$ ) in the reaction containing $10 \mathrm{mmol} \mathrm{I}^{-1} \mathrm{~L}-\mathrm{DOPA}$ as a substrate $\left(T=25{ }^{\circ} \mathrm{C}\right)$.

All the measurements were performed in triplicate, and in the $95 \%$ confidence interval the results showed no significant difference.

\subsection{Measurements of catechol concentration}

Catechol concentration was measured using HPLC (LCAT10, Shimadzu, Japan) at $30{ }^{\circ} \mathrm{C}$ with a reverse phase C18 $125 \mathrm{~mm} \times 4 \mathrm{~mm} \times 5$ um column (LiChrospher $5 \mathrm{u}$ RP-18 100 A, Phenomenex, USA), and a UV detector at $280 \mathrm{~nm}$ according to the method described by Jurinjak Tušek et al. ${ }^{17}$

\subsection{Catechol oxidation}

Catechol oxidation was performed in a glass batch reactor $(V=50 \mathrm{ml})$ with reaction volume of $10 \mathrm{ml}$. The reaction was carried out at $25{ }^{\circ} \mathrm{C}$ in phosphate buffer $\left(0.1 \mathrm{mmol} \mathrm{I}^{-1}, \mathrm{pH}\right.$ 6.8). Initial concentration of catechol was $7.7 \mathrm{mmol} \mathrm{I}^{-1}$. The reaction started with the addition of $0.1 \mathrm{ml}$ of PPO suspension to $7.7 \mathrm{mmol} \mathrm{I}^{-1}$ aqueous catechol solution to give a final PPO concentration in the reactor of $0.0011 \mathrm{mg} \mathrm{ml}^{-1}$. The reaction mixture was stirred with a magnetic stirrer (800 rpm, Tehtnica, Czech Republic) and catechol concentration in the samples was monitored by HPLC as described above. Experiments were performed without additional aeration. An oximeter (Optical Oxygen Meter - FireStingO ${ }_{2}$, Denmark) was used for measurement of dissolved oxygen concentration in the reaction mixture.

\subsection{Modelling and data handling}

Enzyme operational stability decay rate was described by the first order kinetics according to Eq (1).

$$
\frac{\mathrm{d} S \cdot A .}{\mathrm{d} t}=-k_{\mathrm{d}} \cdot S \cdot A \text {. }
$$

where S.A. is specific activity $\left(\mathrm{U} \mathrm{mg}^{-1}\right), t$ is time $(\mathrm{h})$, and $k_{\mathrm{d}}$ is decay rate constant $\left(\mathrm{h}^{-1}\right)$. Decay rate constant was estimated by the nonlinear regression analysis using the least squares method implemented in the SCIENTIST software (MicroMath ${ }^{\circledR}$, Salt Lake City, USA). It was evaluated by fitting the model to the experimental data. The calculated data were compared with the experimental data, recalculated in the optimization routine, and fed again to the integration step until a minimal error between experimental and integrated values was achieved. The residual was defined as the sum of the squares of the differences between the experimental and the calculated data. "Episode" algorithm for the stiff system of differential equations, implemented in the SCIENTIST software, was used for simulations of batch reactor mathematical models.

\section{Results and discussion}

\subsection{Effect of pH on PPO activity}

Once the PPO was partially purified $\left(S . A .=5018 \pm 198 \mathrm{U} \mathrm{mg}^{-1}\right)$, the effect of $\mathrm{pH}$ in the range from 5 to 9 on PPO activity was determined. This range was chosen based on previous reports where different authors reported that optimal $\mathrm{pH}$ values range from 5 to $7 .{ }^{18-21}$ It was found that optimal $\mathrm{pH}$ correlates with literature data (Fig. 1) but, also, that it depends on the chosen buffer. When the $0.1 \mathrm{mmol} \mathrm{I}^{-1}$ sodium acetate buffer was used, $\mathrm{pH}$ optimum was determined to be 6 , while when $0.1 \mathrm{mmol} \mathrm{I}^{-1}$ sodium phosphate was used, the optimal $\mathrm{pH}$ was 6.8. Therefore, $0.1 \mathrm{mmol} \mathrm{I}^{-1}$ sodium phosphate was used in all further experiments. Additionally, $\mathrm{Ni} \mathrm{Ei-}$ dhin et al. ${ }^{19}$ reported that activity of PPO from Bramley's Seedling apple sharply decreases at $\mathrm{pH}$ higher than 7 (for $\mathrm{pH} 7.5$, enzyme retained only $20 \%$ of its initial activity). The same effect was not noticed in this research using partially purified apple PPO. It was found that, in the $\mathrm{pH}$ range from 5 to 8 , PPO retains more than $85 \%$ of its initial activity, indicating that it is more stable than the PPO from Bramley's Seedling apple.

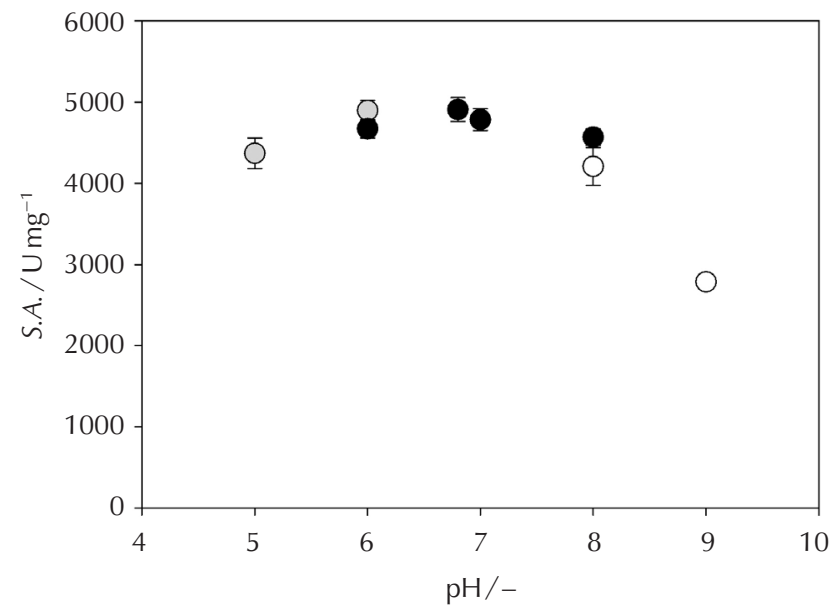

Fig. 1 - Effect of $\mathrm{pH}$ on PPO activity; $0.1 \mathrm{mmol} \mathrm{I}^{-1}$ sodium acetate buffer, $0.1 \mathrm{mmol} \mathrm{I}^{-1}$ sodium phosphate buffer and $\bigcirc 0.1 \mathrm{mmoll}^{-1}$ Tris-HCl buffer

Slika 1 - Utjecaj pH-vrijednosti na aktivnost enzima PPO; $0,1 \mathrm{mmoll}^{-1}$ natrijev acetatni pufer, $0,1 \mathrm{mmoll}^{-1}$ natrijev fosfatni pufer i $\bigcirc 0,1 \mathrm{mmoll}^{-1}$ Tris- $\mathrm{HCl}$ pufer

\subsection{Effect of temperature on the PPO activity and stability}

PPO activity was determined in the temperature range from 10 to $50{ }^{\circ} \mathrm{C}$ in $0.1 \mathrm{mmol} \mathrm{I}^{-1}$ phosphate buffer at $\mathrm{pH}$ 6.8. It was found that optimal temperature for partially purified PPO was $25{ }^{\circ} \mathrm{C}$, but enzyme retained more than $90 \%$ of its initial activity in temperature range from 10 to $50{ }^{\circ} \mathrm{C}$ (Fig. 2). Observed data are opposite to the report of Ni Eidhin et al. ${ }^{19}$ who found that PPO from Bramley's Seedling apple shows optimal temperature at $30{ }^{\circ} \mathrm{C}$, and retains from 60 to $80 \%$ of its initial activity in temperature range from $10{ }^{\circ} \mathrm{C}$ to $50{ }^{\circ} \mathrm{C}$. 


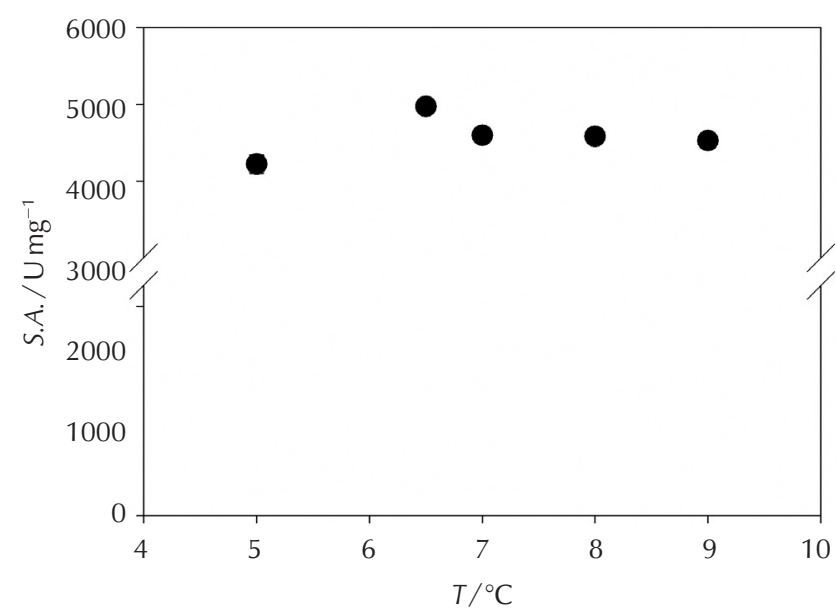

Fig. 2 - Effect of temperature on PPO activity

Slika 2 - Utjecaj temperature na aktivnost enzima PPO

PPO stability during storage was monitored once the PPO was partially purified and stored $\left(-20^{\circ} \mathrm{C}\right)$. Samples were taken during 228 days, and the results are presented in Fig. 3a. According to the obtained results, it can be concluded that no change in activity during 228 days had occurred.

In order to investigate PPO stability suspended in buffer (0.1 mmol I-1 ${ }^{-1}$ phosphate buffer, $\mathrm{pH} 6.8$, containing Triton $\mathrm{X}-100(\varphi=0.1 \%))$ and stored during $164 \mathrm{~h}$ at two different temperatures $\left(4\right.$ and $25{ }^{\circ} \mathrm{C}$ ), the samples were withdrawn with time and PPO activity was measured (Fig. 3b). As may be observed, the PPO in solution was still stable with a slight decrease in activity when stored at $4{ }^{\circ} \mathrm{C}$. The temperature of $25{ }^{\circ} \mathrm{C}$ (shown to be optimal temperature for substrate oxidation) had a significant effect on PPO stability. It was noticed that PPO retained less than $50 \%$ of its initial activity after $168 \mathrm{~h}$.

In order to predict the time when the activity will decrease under $10 \%$ of PPO initial activity, decay rate con- stants were determined assuming the first order kinetics. It was calculated that PPO stability decay rate constant for PPO stored at $4{ }^{\circ} \mathrm{C}$ was $0.00011 \pm 0.00002 \mathrm{~h}^{-1}$ and $0.00442 \pm 0.00017 \mathrm{~h}^{-1}$ for PPO stored at $25^{\circ} \mathrm{C}$. Based on obtained results and according to the mathematical model predictions, after seven months of storage at $4{ }^{\circ} \mathrm{C}$, PPO will lose $50 \%$ of its initial activity and $90 \%$ after more than two years. On the other hand, when the activity was measured at $25{ }^{\circ} \mathrm{C}, 50 \%$ of activity was lost after six days and $90 \%$ after 21 days. Considering long-term processes conducted at $25{ }^{\circ} \mathrm{C}$, obtained result is not so promising, but in order to overcome that disadvantage, biocatalyst immobilization is often implemented. ${ }^{22}$ Immobilization of PPO can protect it from denaturation by organic co-solvents, increase their stability in general, ${ }^{23}$ facilitate the separation of reaction products, ${ }^{7}$ and maintain good catalytic efficiency over many reaction cycles. ${ }^{24,25}$ Thus, this could be a possible solution for long-term processes.

\subsection{Catechol oxidation catalysed with partially purified apple PPO}

As mentioned in the introduction, catechol is released into the environment from a variety of industrial sources ${ }^{1}$, and together with different polyphenolic compounds, presents a serious ecosystem burden. ${ }^{26}$ Therefore, the removal of catechol from water or wastewaters is of great importance. Many reports have suggested that PPO has high affinity towards catechol, $18,19,27-30$ therefore, catechol was chosen as a model substrate in wastewater purification. Batch mode catechol oxidation was performed in $10 \mathrm{ml}$ scale. The reaction was carried out at $25{ }^{\circ} \mathrm{C}$ in phosphate buffer (0.1 mmoll-1, $\mathrm{pH} 6.8$ ), which was determined as optimal for PPO. Initial concentration of catechol was $7.7 \mathrm{mmoll}^{-1}$, while initial oxygen concentration was determined to be $0.186 \mathrm{mmol} \mathrm{I}^{-1}$. The mixture was not aerated additionally, so the oxygen supply was provided only through the boundary layer atmosphere/reaction mixture. Results are presented in Fig. 4.
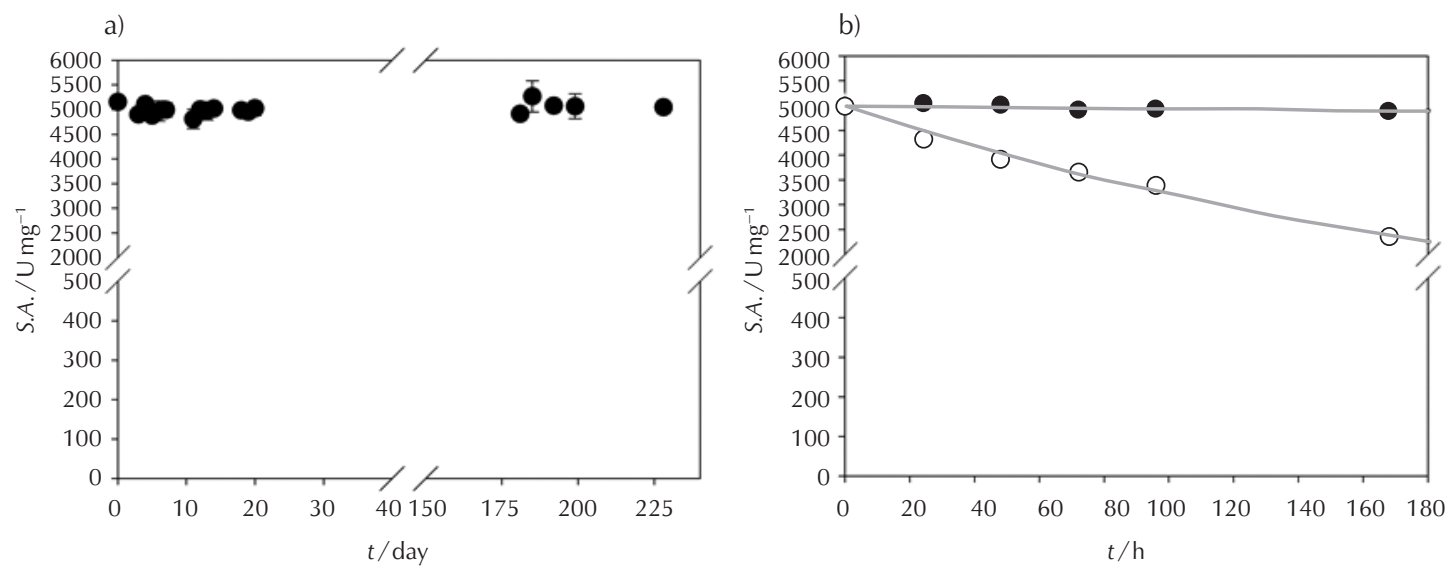

Fig. 3 - Temperature stability of PPO at a) $-20{ }^{\circ} \mathrm{C}$ and b) $4{ }^{\circ} \mathrm{C}$ and $\bigcirc 25^{\circ} \mathrm{C}$, - mathematical model Slika 3 - Temperaturna stabilnost enzima PPO pri a) $-20{ }^{\circ} \mathrm{C}$ i b) $4^{\circ} \mathrm{C}$ i $\bigcirc 25^{\circ} \mathrm{C}$, - matematički model 


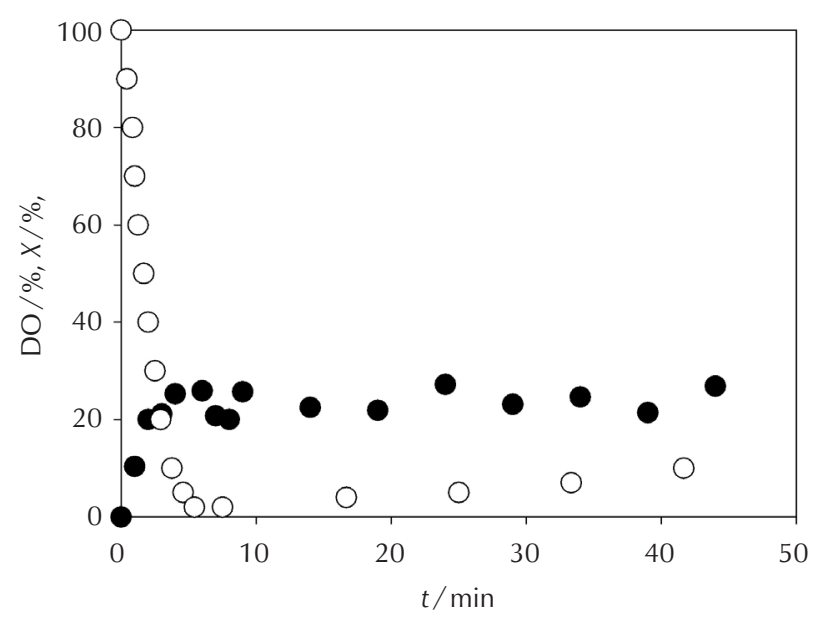

Fig. 4 - Catechol oxidation in a batch reactor $(-$ catechol conversion, $X ; O$ dissolved oxygen concentration, DO)

Slika 4 - Oksidacija katehola u šaržnom reaktoru $(\bullet$ konverzija katehola, X; $\bigcirc$ koncentracija otopljenog kisika, DO)

Catechol conversion of $25 \%$ was achieved after 5 min of reaction (Fig. 4). According to the results of dissolved oxygen concentration (Fig. 4), reaction time of 5 min was also the time when all the oxygen dissolved in the mixture was consumed, which confirmed that PPO is an oxygen-dependent enzyme, as well as that oxygen is the second substrate in the reaction. The obtained product of catechol oxidation is probably quinone, ${ }^{31}$ which plants usually utilize to synthesize melanins - pigments that cause the damaged tissues to turn reddish-brown ${ }^{32,33}$ and it is less toxic than catechol.

In the literature, for polyphenol removal, enzyme laccase is usually proposed (L-DOPA, ${ }^{34}$ L-DOPA and catechol, ${ }^{17}$ coniferyl alcohol ${ }^{35}$ ). Laccase is an enzyme that belongs to the group of effective enzymes capable of catalysing the oxidation of different phenolics. Research performed by Tišma et al. ${ }^{34}$ confirmed that laccase can be used for L-DOPA oxidation and that the reaction is strongly dependent on dissolved oxygen concentration; therefore, continuous aeration had great effect on reaction rate. Similar results were obtained in the research performed by Jurinjak Tušek et al. ${ }^{17}$ As for the results of catechol oxidation, the results obtained in this research (maximal conversion) were similar to the results obtained when laccase was used for catechol oxidation where the maximal conversion of $30 \%$ was achieved (data not presented). The only significant difference was the reaction time; whereas 5 min was enough for PPO, it took almost $2 \mathrm{~h}$ to achieve the same conversion with enzyme laccase. Obtained results indicate that partially purified PPO could be a better solution than laccase for polyphenol oxidation/removal. Also, with additional process optimization (mainly continuous aeration), even better results (higher conversion) could be expected.

\subsection{Substrate (polyphenol) specificity of partially purified apple PPO}

The composition of wastewaters is never simple, and it contains a variety of organic and inorganic compounds. Among them, there are different phenolic compounds, not just catechol. ${ }^{1}$ In order to determine which other polyphenolic compounds could be removed/oxidised by partially purified PPO, PPO specificity was investigated towards L-DOPA (-)-epicatechin, (-)-epigallocatechin-3-gallate, (+)-catechin, caffeic acid, chlorogenic acid, 4-methylcatechol, L-tyrosine and trans-ferullic acid.

The reaction was performed under optimal conditions regarding $\mathrm{pH}$ and temperature $\left(0.1 \mathrm{mmol} \mathrm{I}^{-1}\right.$ phosphate buffer, $\mathrm{pH} 6.8 ; T=25^{\circ} \mathrm{C}$ ). Three different substrate concentrations $\left(1,2.5\right.$, and $\left.10 \mathrm{mmoll}^{-1}\right)$ were studied, and the results are presented in Table 1.

Table 1 - Substrate specificity of partially purified PPO from apple variety Idared

Tablica 1 - Supstratna specifičnost djelomično pročišćenog enzima PPO iz sorte jabuka ldared

\begin{tabular}{l|r|r}
\hline Substrate & C $/$ mmol I $^{-1}$ & $\begin{array}{c}\text { Relative activity } / \%^{*} \\
\text { Relativna aktivnost } \%\end{array}$ \\
\hline \multirow{2}{*}{ L-DOPA } & 10.0 & 100.0 \\
& 2.5 & 28.8 \\
(-)-epicatechin & 1 & 12.3 \\
(-)-epikatehin & 10.0 & 272.8 \\
& 2.5 & 211.5 \\
(-)-epigallocatechin-3-galate & 1 & 26.9 \\
(-)-epigalokatehin-3-galat & 2.5 & 8.6 \\
& 1 & 5.3 \\
(+)-catechin & 10.0 & 0.5 \\
(+)-katehin & 2.5 & 407.4 \\
& 1 & 251.0 \\
caffeic acid & 10.0 & 28.3 \\
kavena kiselina & 2.5 & 62.5 \\
& 1 & 60.6 \\
chlorogenic acid & 10.0 & 11.9 \\
klorogenska kiselina & 2.5 & 116.0 \\
\hline \multirow{2}{*}{ 4-methylcatechol } & 1 & 81.1 \\
4-metilkatehol & 10.0 & 12.8 \\
\hline \multirow{2}{*}{ L-tyrosine } & 2.5 & 255.8 \\
L-tirozin & 1 & 162.8 \\
\hline \multirow{2}{*}{ trans-ferullic acid } & 10.0 & 9.3 \\
trans-ferulinska kiselina & 2.5 & 0.0 \\
\hline Relative activities are cal & 1 & 0.0 \\
\hline
\end{tabular}

${ }^{*}$ Relative activities are calculated as \% of activity determined with L-DOPA $\left(10 \mathrm{mmol} \mathrm{I}^{-1}\right)$

The highest activity was achieved using catechin, followed by epicatechin and 4-methylcatechol, then chlorogenic acid, L-DOPA, caffeic acid, and epigallocatechin-3-gallate. 
Affinities towards mentioned substrates were expected, since they can all be found in apples. ${ }^{19}$ It was found that PPO has no activity towards monophenols, L-tyrosine and trans-ferullic acid. Tyrosine has already been reported to be a poor substrate for apple PPO, 15,19,36 but it was shown to be a substrate for PPO isolated from other fruits, such as jackfruit. ${ }^{28}$ In general, partially purified apple PPO had higher affinity towards di-phenolic then mono-phenolic compounds. Similar results were obtained with PPO originated from different fruits, like jackfruit, ${ }^{28}$ Barbados cherry, ${ }^{37}$ and other plant species, like peppermint, ${ }^{38}$ dormant saffron $^{39}$ and butter lettuce, ${ }^{40}$ indicating that they can also be used for polyphenol removal, as individual enzymes or in combination with others (for example, if the PPO is isolated from different fruit waste).

Briefly, partially purified PPO could be effectively used for the removal of the most studied polyphenols (i.e. diphenol), with the exception of monophenols, such as L-tyrosine and trans-ferullic acid. For monophenol removal, some other enzymes or PPO from different sources should be used.

\subsection{Effect of inhibitors and organic solvents on PPO activity}

Wastewaters can also contain many compounds that can inhibit or deactivate PPO. To determine the effect of different inhibitors on partially purified apple PPO activity, three different concentrations of inhibitors $(0.1,1$, and $10 \mathrm{mmol} \mathrm{I}^{-1}$ ) were investigated. The PPO activity without the presence of inhibitors was taken to be $100 \%$. As given in Table 2, sodium tetraborate-decahydrate showed $69 \%$ of inhibition on partially purified PPO activity when used in the highest investigated concentration $\left(10 \mathrm{mmol}^{-1}\right)$.

Table 2 - Effect of inhibitors on PPO activity

Tablica 2 - Utjecaj inhibitora na aktivnost enzima PPO

\begin{tabular}{l|c|c}
\hline Inhibitor & $\mathrm{c} / \mathrm{mmol} \mathrm{I}^{-1}$ & $\begin{array}{c}\text { Inhibition } / \%^{*} \\
\text { Inhibicija } \%\end{array}$ \\
\hline sodium tetraborate decahydrate & 10.0 & 69 \\
natrijev tetraborat dekahidrat & 1.0 & 14 \\
sodium chloride & 0.1 & 10 \\
natrijev klorid & 10.0 & 16 \\
& 1.0 & 10 \\
EDTA-2Na & 0.1 & 5 \\
& 10.0 & 17 \\
\hline
\end{tabular}

*Inhibitions are expressed as \% of inhibition compared with the activity determined with L-DOPA (10 $\left.\mathrm{mmol}^{-1}\right)$ without addition of inhibitor

The minimum inhibition of PPO activity was noticed when EDTA-2 $\mathrm{Na}$ and sodium chloride were used, which is in agreement with reports of Geetha et $a l{ }^{28}$, but opposite to the findings of Ni Eidhin et al. ${ }^{19}$ Obtained results indicate that PPO could not be effectively used for polyphenol removal if the wastewater contains large amounts of sodium tetraborate decahydrate.

Data on the influence of organic solvents on partially purified PPO are outlined in Table 3. PPO activity decreased with the increase in the amount of investigated organic solvent, and enzyme activity at the highest concentration of solvent was inhibited by 39 or $40 \%$. Observed decrease in PPO activity in the presence of organic solvents could be attributed to enzyme denaturation.

Table 3 - Effect of organic solvent on PPO activity

Tablica 3 - Utjecaj organskih otapala na aktivnost enzima PPO

\begin{tabular}{l|c|c}
\hline $\begin{array}{l}\text { Organic solvent } \\
\text { Organsko otapalo }\end{array}$ & $\varphi / \%$ & $\begin{array}{c}\text { Inhibition } / \% * \\
\text { Inhibicija/\% }\end{array}$ \\
\hline ethanol & 5.0 & 40 \\
etanol & 2.0 & 21 \\
& 1.0 & 11 \\
DMSO & 5.0 & 39 \\
& 2.0 & 22 \\
\hline
\end{tabular}

* Inhibitions are expressed as \% of inhibition compared with the activity determined with L-DOPA $\left(10 \mathrm{mmol}^{-1}\right)$ without addition of organic solvent

\section{Conclusion}

The study of catechol oxidation catalysed by partially purified apple PPO revealed the highest enzyme activity at $\mathrm{pH} 6.8$, in phosphate buffer $0.1 \mathrm{mmol} \mathrm{I}^{-1}$ and at temperature of $25{ }^{\circ} \mathrm{C}$. At optimized process conditions, partially purified PPO could be efficiently used for catechol removal from the model wastewater. Besides catechol, partially purified PPO also shows affinity towards several different diphenols, like catechin, epicatechin, 4-methylcatechol, chlorogenic acid, L-DOPA, caffeic acid, and epigallocatechin-3-gallate, but it shows no affinity towards the mono-phenolic substrates, such as L-tyrosine and trans-ferullic acid. In addition, the presence of sodium tetraborate-decahydrate moderately inhibits PPO activity; therefore, partially purified PPO cannot be used for the treatment of wastewaters where this compound is present in higher concentrations.

Based on the obtained results, it can be concluded that partially purified PPO has great potential in wastewater treatment. With some additional process optimisation (complex model solutions, additional aeration, enzyme immobilization, etc.), even better results could be expected. As a final step, apple waste (apple peel and especially the apple core contain the highest amount of PPO) should be studied in the process of polyphenol removal by using one waste stream (apple residue) in treatment of the other (wastewater loaded by phenols). 


\section{List of abbreviations and symbols Popis kratica i simbola}

$\begin{array}{ll}\text { DMSO } & \text { - dimethyl sulfoxide } \\ & \text { - dimetil sulfoksid } \\ \text { DO } & \text { - dissolved oxygen concentration } \\ & \text { - koncentracija otopljenog kisika } \\ \text { EDTA-2Na } & \text { - ethylenediaminetetraacetic acid disodium salt } \\ & \text { - dinatrijeva sol etilendiaminotetraoctene kiseline } \\ \text { L-DOPA } & - \text { L-3,4-dihydroxyphenylalanine } \\ & - \text { L-3,4-dihidroksifenilalanin } \\ \text { PPO } & \text { - polyphenol oxidase } \\ & \text { - enzim polifenol oksidaza } \\ \text { S.A. } & \text { - specific activity } \\ & - \text { specifična aktivnost }\end{array}$

\section{References \\ Literatura}

1. H. Chen, J. Yao, F. Wang, Y. Zhou, K. Chen, R. Zhuang, M. M. F. Choi, G. Zaray, Toxicity of three phenolic compounds and their mixtures on the gram-positive bacteria Bacillus subtilis in the aquatic environment, Sci. Total Environ. 408 (2010) 1043-1049, doi: https://doi.org/10.1016/j.scitotenv.2009.11.051.

2. Environmental Protection Agency, Sampling and Analysis Procedure for Screening of Priority Pollutants, Environment Monitoring and Support Laboratory (1977) Cununnati, Ohio, USA.

3. Faust SD, Aly OM (1983) Chemistry of water treatment. Butterworth, Woburn.

4. K. Shakir, H. F. Ghoneimy, A. F. Elkafrawy, Sh. G. Beheir, M. Refaat, Removal of catechol from aqueous solutions by adsorption onto organophilic-bentonite, J. Hazard. Mater. 150 (2008) 765-773, doi: https://doi.org/10.1016/j.jhazmat.2007.05.037.

5. S. Mukherjee, B. Basa, B. Bhunia, A. Dey, B. Mondal, Potential use of polyphenol oxidases (PPO) in the bioremediation of phenolic contaminants containing industrial wastewater, Rev. Environ. Sci. Biotechnol. 12 (2013) 61-73, doi: https:// doi.org/10.1007/s11157-012-9302-y.

6. T. P. Chung, H. Y. Tseng, R. S. Juang, Mass transfer effect and intermediate detection for phenol degradation in immobilized Pseudomonas putida systems, Process Biochem. 38 (2003) 1497-1507, doi: https://doi.org/10.1016/S00329592(03)00038-4.

7. N. Duran, E. Esposito, Potential applications of oxidative enzymes and phenoloxidase-like compounds in wastewater and soil treatment: a review, Appl. Catal. B-Environ. 28 (2000) 83-99, doi: https://doi.org/10.1016/S09263373(00)00168-5.

8. J. Karam, J. A. Nicell, Potential applications of enzymes in waste treatment, J. Chem. Technol. Biotechnol. 69 (1997) 141-153, doi: https://doi.org/10.1002/(SICI)10974660(199706)69:2<141::AID-JCTB694>3.0.CO;2-U.

9. A. M. Klibanov, B. N. Alberti, E. D. Morris, L. M. Felshin, Enzymatic removal of toxic phenols and anilines from waste waters, J. Appl. Biochem. 2 (1980) 414-421.

10. M. Y. Arica, Immobilization of polyphenol oxidase on carboxymethylcellulose hydrogel beads: preparation and characterization, Polym. Int. 49 (2000) 775-781, doi: https:// doi.org/10.1002/1097-0126(200007)49:7<775::AID$\mathrm{PI} 454>3.0 . \mathrm{CO} ; 2-\mathrm{O}$.
11. K. N. Niladevi, P. Prema, Immobilization of laccase from Streptomyces psammoticus and its application in phenol removal using packed bed reactor, World J. Microbiol. Biotechnol. 24 (2008) 1215-1222, doi: https://doi.org/10.1007/s11274007-9598-x.

12. K. Yamada, T. Inoue, Y. Akiba, A. Kashiwada, K. Matsuda, M. Hirata, Removal of $p$-alkylphenols from aqueous solutions by combined use of mushroom tyrosinase and chitosan beads, Biosci. Biotechnol. Biochem. 70 (2006) 2467-2475, doi: https://doi.org/10.1002/app.30947.

13. B. Bukowska, S. Kowalaska, Phenol and catechol induce prehemalytic and hemolytic changes in human erythrocytes, Toxicol. Lett. 152 (2004) 73-84, doi: https://doi. org/10.1016/j.toxlet.2004.03.025.

14. F. Ivković, The assortment of apples in production in the EU and Croatia and which varieties to plant, Glasnik zaštite bilja 5 (2011) 17-19. (Published in Croatian)

15. I. Strelec, P. Burić, I. Janković, T. Kovač, M. Molnar, Inhibitory effect of coumarin derivatives on apple (cv. Idared) polyphenol oxidase, Croat. J. Food Sci. Technol. 9 (2017) 57-65, doi: https://doi.org/10.17508/CJFST.2017.9.1.08.

16. M. M. Bradford, A rapid and sensitive method for the quantitation of microgram quantities of protein utilizing the principle of protein-dye binding, Anal. Biochem. 72 (1976) 248254, doi: https://doi.org/10.1016/0003-2697(76)90527-3.

17. A. Jurinjak Tušek, M. Tišma, V. Bregović, A. Pričar, Ž. Kurtanjek, B. Zelić, Enhancement of phenolic compounds oxidation using laccase from Trametes versicolor in a microreactor, Biotechnol. Bioprocess. E. 18 (2013) 686-696, doi: https:// doi.org/10.1007/s12257-012-0688-8.

18. M. Oktay, I. Küfreviolu, I. Kocaçalişkan, H. Şakirolu, Polyphenoloxidase from Amasya apple, J. Food Sci. 60 (1995) 494-496, doi: https://doi.org/10.1111/j.1365-2621.1995. tb09810.x.

19. D. M. Ni Eidhin, E. Murohy, D. O'Beirne, Polyphenol oxidase from apple (Malus domestica Borkh. cv Bramley's Seedling): Purification strategies and characterization, J. Food Sci. 71 (2006) 51-58, doi: https://doi. org/10.1111/j.1365-2621.2006.tb12388.x.

20. A. M. C. N. Rocha, M. P. Cano, M. A. M. Galeazzi, A. M. M. B. Morais, Characterization of 'Starking' apple polyphenoloxidase, J. Sci. Food Agric. 77 (1998) 527-534, doi: https:// doi.org/10.1002/(SICI)1097-0010(199808)77:4<527::AIDJSFA76>3.0.CO;2-E.

21. C. A. Weemaes, L. R. Ludikhuyze, I. Van den Broeck, M. E. Hendrickx, P. P. Tobback, Activity, electrophoretic characteristics and heat in activation of polyphenoloxidases from apples, avocados, grapes, pears and plums, Lebensm.-Wiss. Technol. 31 (1998) 44-49, doi: https://doi.org/10.1006/ fstl.1997.0302.

22. G. Stojkovič, I. Plazl, P. Žnidaršič Plazl, L-Malic acid production within a microreactor with surface immobilised fumarase, Microfluid. Nanofluid. 10 (2011) 627-635, doi: https://doi.org/10.1007/s10404-010-0696-y.

23. A. D'Annibale, S. R. Stazi, V. Vinciguerra, G. Giovannozzi Sermanni, Oxirane immobilized Lentinula edodes laccase: stability and phenolics removal efficiency in olive mill wastewater, J. Biotechnol. 77 (2000) 265-273, doi: https://doi. org/10.1016/S0168-1656(99)00224-2.

24. P. Brandi, A. D’Annibale, C. Galli, P. Gentili, A. S. N. Pontes, In search for practical advantages from the immobilisation of an enzyme: the case of laccase, J. Mol. Catal. B-Enzym. 41 (2006) 61-69, doi: https://doi.org/10.1016/j. molcatb.2006.04.012.

25. G. Palmieri, P. Giardina, G. Sannia, Laccase-mediated Rema- 
zol brilliant blue R decolorization in a fixed-bed bioreactor, Biotechnol. Progr. 2 (2005) 1436-1441, doi: https://doi. org/10.1021/bp050140i.

26. J. Michałowicz, W. Duda, Phenols - Sources and toxicity, Poli. J. Environ. Stud. 16 (2007) 347-362.

27. J. R. Das, S. G. Bhat, L. R. Gowda, Purification and characterization of a polyphenol oxidase from Kew cultivar of Indian pineapple fruit, J. Agric. Food Chem. 45 (1997) 2031-2035, doi: https://doi.org/10.1021/jf9607674.

28. R. Y. Geetha, R. Arulvel, E. Selvarajan, Studies of kinetic parameters and biochemical characteristics of polyphenol oxidase purified from jackfruit (Artocarpus heterophyllus) waste, Int. J. Pharm. Pharm. Sci. 6 (2014) 473-478.

29. M. Siddiq, N. K. Sinha, J. N. Cash, Characterization of polyphenoloxidase from Stanley plums, J. Food Sci. 57 (1992) 1177 1179, doi: https://doi.org/10.1111/j.1365-2621.1992. tb11292.x.

30. P. Zhou, N. L. Smith, C. Y. Lee, Potential purification and some properties of Monroe apple peel polyphenol oxidase, J. Agric. Food Chem. 41 (1993) 532-536, doi: https://doi. org/10.1021/jf00028a004

31. C. Queiroz, M. L. M. Lopes, E. Fialho, V. L. Valente-Mesquita, Polyphenol Oxidase: Characteristics and mechanisms of browning control, Food Rev. Int. 24 (2008) 361-375, doi: https://doi.org/10.1080/87559120802089332.

32. J. C. Espín, P. A. García-Ruiz, J. Tudela, R. Varón, F. García-Cánovas, Monophenolase and diphenolase reaction mechanisms of apple and pear polyphenol oxidases, J. Agric. Food Chem. 46 (1998) 2968-2975, doi: https://doi. org/10.1021/jf971045v.

33. M. J. Peñalver, L. G. Fenoll, J. N. Rodríguez-López, P. A.
García-Ruiz, F. García-Molina, R. Varón, F. García-Cánovas, J. Tudela, Reaction mechanism to explain the high kinetic autoactivation of tyrosinase, J. Mol. Catal. B-Enzym. 33 (2005) 35-42, doi: https://doi.org/10.1016/j.molcatb.2005.02.002.

34. M. Tišma, P. Žnidaršič-Plazl, I. Plazl, B. Zelić, Đ. Vasić-Rački, Modelling of L-DOPA oxidation catalysed by laccase, Chem. Biochem. Eng. Q. 22 (2008) 307-313.

35. M. Tišma, P. Žnidaršič-Plazl, I. Plazl, B. Zelić, Đ. Vasić-Rački, Oxidation of coniferyl alcohol catalysed by laccase from Trametes versicolor, Acta Chim. Slov. 57 (2010) 110-117.

36. A. M. C. N. Rocha, A. M. M. B. Morais, Characterization of polyphenoloxidase (PPO) extracted from 'Jonagored' apple, Food Control 12 (2001) 85-90, doi: https://doi. org/10.1002/(SICI)1097-0010(199808)77:4<527::AID-JSFA76 > 3.0.CO;2-E

37. V. B. Anil Kumar, T. C. Kishor Mohan, K. Murugan, Purification and kinetic characterization of polyphenol oxidase from Barbados cherry [Malpighia glabra L.], Food Chem. 110 (2008) 328-333, doi: https://doi.org/10.1016/j.foodchem.2008.02.006.

38. D. Kavrayan, T. Aydemir, Partial purification and characterisation of polyphenoloxidase from peppermint [Mentha piperita], Food Chem. 74 (2001) 147-54, doi: https://doi. org/10.1016/S0308-8146(01)00106-6.

39. S. Saiedian, E. Keyhani, J. Keyhani, Polyphenol oxidase activity in dormant saffron [Crocus sativus L.] corm, Acta Physiol. Plant. 29 (2007) 463-471, doi: https://doi.org/10.1007/ s11738-007-0056-z.

40. U. Gawlik-Dziki, Z. Złotek, M. Swieca, Characterisation of polyphenol oxidase from butter lettuce [Lactuca sativa varcapitata L.], Food Chem. 107 (2008) 129-135, doi: https:// doi.org/10.1016/j.foodchem.2007.07.068.

\section{SAŽETAK}

\section{Potencijalna primjena polifenol oksidaze porijeklom iz jabuka u bioremedijaciji fenolnih onečišćujućih tvari \\ Anita Šalić, ${ }^{\prime}$ Ivica Strelec, ${ }^{b}$ Bruno Zelića i Marina Tišma ${ }^{\text {b* }}$}

Fenolni spojevi, poput primjerice katehola, dospijevaju u okoliš iz različitih industrija i predstavljaju ozbiljni ekološki problem. U ovom radu istraživana je mogućnost primjene djelomično pročišćene polifenol oksidaze (PPO) iz jabuke u bioremedijaciji različitih fenolnih onečišćujućih tvari. S ciljem optimiranja procesnih uvjeta, određeni su optimalni $\mathrm{pH}$ i temperatura za aktivnost PPO-a. Za provjeru mogućnosti primjene PPO-a u obradi otpadnih voda, mjeren je afinitet PPO-a prema različitim fenolnim spojevima kao i utjecaj nekih soli i organskih otapala na njenu aktivnost. Djelomično pročišćen PPO ima maksimalnu aktivnost pri pH 6,8 i $2525^{\circ} \mathrm{C}$, a više od $85 \%$ maksimalne aktivnosti pokazuje u području pH od 5 do 8 , a više od $90 \%$ svoje maksimalne aktivnosti u temperaturnom rasponu od 10 to $50{ }^{\circ} \mathrm{C}$.

Pokazano je da PPO ima veći afinitet prema različitim difenolnom spojevima, dok ne pokazuje afinitet prema monofenolnim spojevima. Natrijev tetraborat dekahidrat ima mali inhibitorni učinak na aktivnost PPO-a, dok utjecaj organskih otapala ( $\varphi=5 \%$ ) uzrokuje $40 \%$-tni gubitak aktivnosti PPO-a. Oksidacijom katehola pomoću PPO-a pri optimalnim procesnim uvjetima u kotlastom reaktoru tijekom samo 5 minuta postignuta je 25 \%-tna konverzija. Na temelju provedenih rezultata moguće je zaključiti da djelomično pročišćen PPO ima odgovarajući potencijal za primjenu u obradi otpadnih voda.

\section{Ključne riječi}

Oksidacija katehola, enzimska obrada otpadnih voda, fenolne onečišćujuće tvari, polifenol oksidaza (PPO)

\footnotetext{
a Sveučilište u Zagrebu, Fakultet kemijskog inženjerstva i tehnologije, Marulićev trg 19, 10000 Zagreb

b Sveučilište Josipa Jurja Strossmayera u Osijeku, Prehrambeno-tehnološki fakultet Osijek, Franje Kuhača 20, 31000 Osijek
}

Izvorni znanstveni rad Prispjelo 31. kolovoza 2017. Prihvaćeno 20. listopada 2017. 